\title{
På ville veger? Levende utstillinger av samer i Europa og Amerika
}

CATHRINE BAglo*

Title: Getting off track? Living exhibitions of Sámi in Europe and America.

Abstract: During the nineteenth century, new practices for the representation of otherness were established. One significant manifestation was the living exhibitions of Sami and other native peoples in zoological gardens, amusement parks, world fairs and other urban stages in Europe and America. These exhibitions have usually been perceived as the Western world's staging of primitivity and race within hegemonic discourses based on exploitation and repression. The exhibitions in zoological gardens, in particular, have been considered instrumental in this respect. Although this dominant interpretation has provided important insight into how stereotypical features of cultural difference were normalized and naturalized, it has also seriously obscured the exhibitions' own historicity and, in particular, the agency of the exhibited people themselves. In this dissertation, this a priori victimizing approach to the living exhibitions is challenged. A far more nuanced picture of motivations, experiences and power relations emerges through a detailed study of the Sami participants and their exhibitors, also providing a richer account of the exhibitions' own ethnography.

Key words: Living exhibitions, Sámi, cultural reconstruction, physical anthropology, imperialism, contact zones, the history of affect, authenticity, ANT.

Avhandlinga På ville veger? Levende utstillinger av samer $i$ Europa og Amerika (Baglo 2011), tar utgangspunkt $\mathrm{i}$ et helt særegent fenomen $\mathrm{i}$ vestlig utstillingshistorie, nemlig såkalte "levende utstillinger". Denne utstillingsformen var karakterisert av at representanter for eksotiske og antatt primitive folk ble brakt til museer, dyrehager, fornøyelsesparker, verdensutstillinger og andre utstillingssteder i Europa og Amerika hvor de opptrådte med sitt hverdagsliv i realistisk iscenesatte omgivelser.
Første gangen samer ble framstilt på denne måten var i London i årene 1822-1832, og da nærmest som en tilfeldighet. I et forsøk på å innføre tamreinhold i England hadde naturvitenskapsmannen, samleren og museumsmannen William Bullock brakt rørossamene Jens Thomassen Holm og kona Karen Christiansdatter til landet, som gjetere for en reinsdyrflokk han hadde kjøpt. Etter at reinholdplanen ble kullkastet fordi størsteparten av dyrene døde, og et forsøk på å sette opp et teater- 


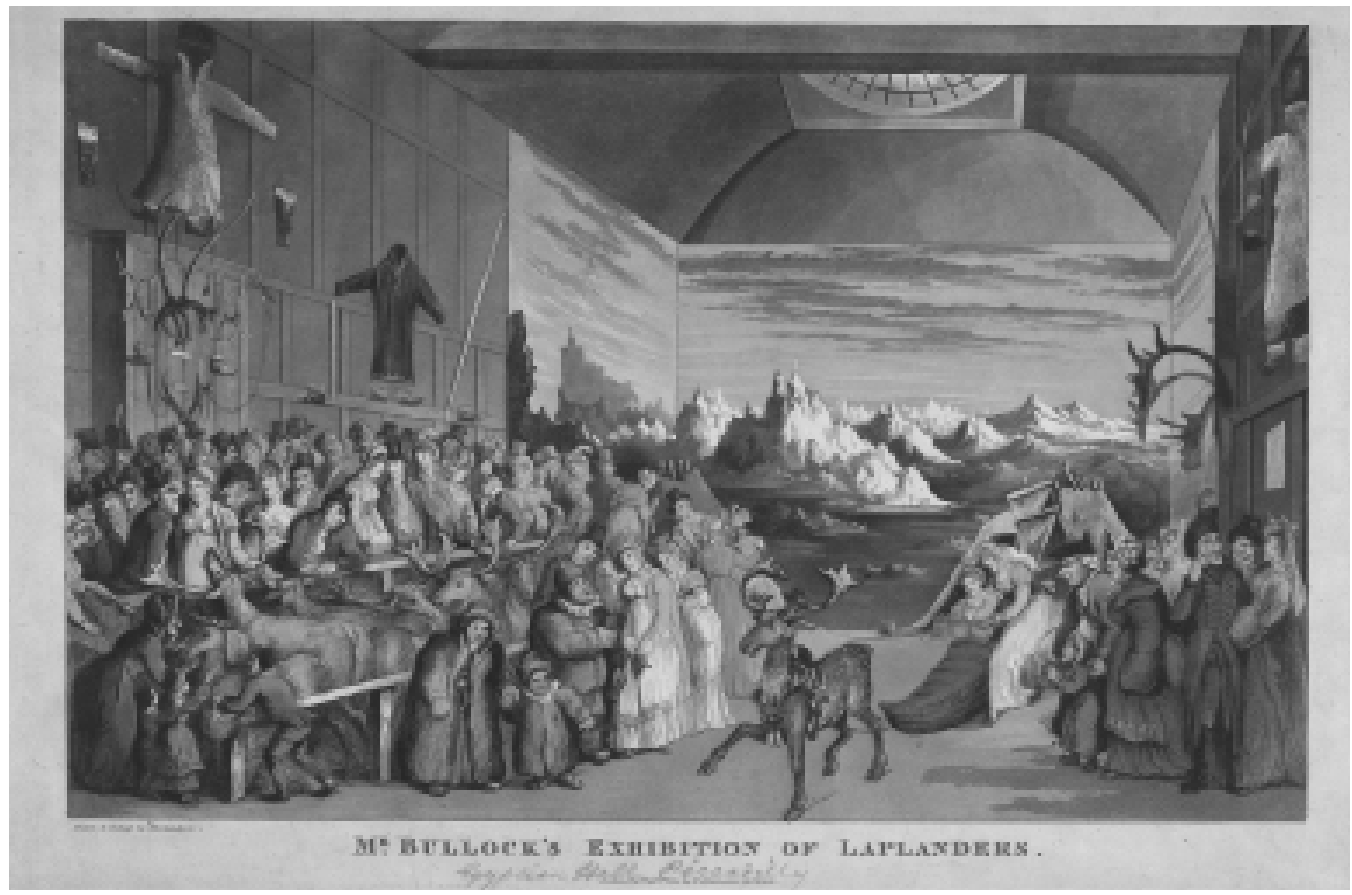

Fig. 1. "Mr. Bullock's Exhibition of Laplanders". Trykk: Thomas Rowlandson. Kilde: Nasjonalbiblioteket, Oslo.

stykke med både samer og reinsdyr også mislyktes, ser det ut til at en utstilling ble en alternativ løsning for å tjene inn utgiftene prosjektet hadde medført. Bullock var en av de første i Europa til å gjøre bruk av såkalte "habitatutstillinger", det vil si utstillinger av utstoppede dyr i gjenskapte miljøer (Wonders 1993: 30), og han ser ut til å ha overført denne teknikken til utstillinga av levende mennesker og dyr. I hvert fall ble samene med sine boliger, eiendeler og gjenlevende dyr installert foran et malt vinterlandskap - et panorama - i den delen av Bullocks museum som gikk under navnet Egyptian Hall. Utstillinga viste seg å bli en stor suksess. Tusenvis av mennesker strømmet til museet for å se familien "drive their rapid sledge round the spacious plains of the Egyptian Hall”, som det het i en samtidig kilde.

Med sin realistiske gjenskaping av miljøer med både virkelige dyr og mennesker, skapte Bullock et utstillingskonsept som foregrep utviklingen med flere tiår. Selv om utstillinger av levende folk skjedde jevnlig både i Amerika og Europa i løpet av første halvdel av 1800tallet, var det likevel først på 1870-og utover at fenomenet ble utbredt. Dette hadde ikke minst sammenheng med den nærmest eksplosive tilkomsten av utstillings- og underholdningsinstitusjoner på denne tida. Vesentlig $\mathrm{i}$ den sammenheng er verdensutstillingene og de store internasjonale utstillingene. Samer opptrådte i tilknytning til verdensutstillinga $\mathrm{i}$ 


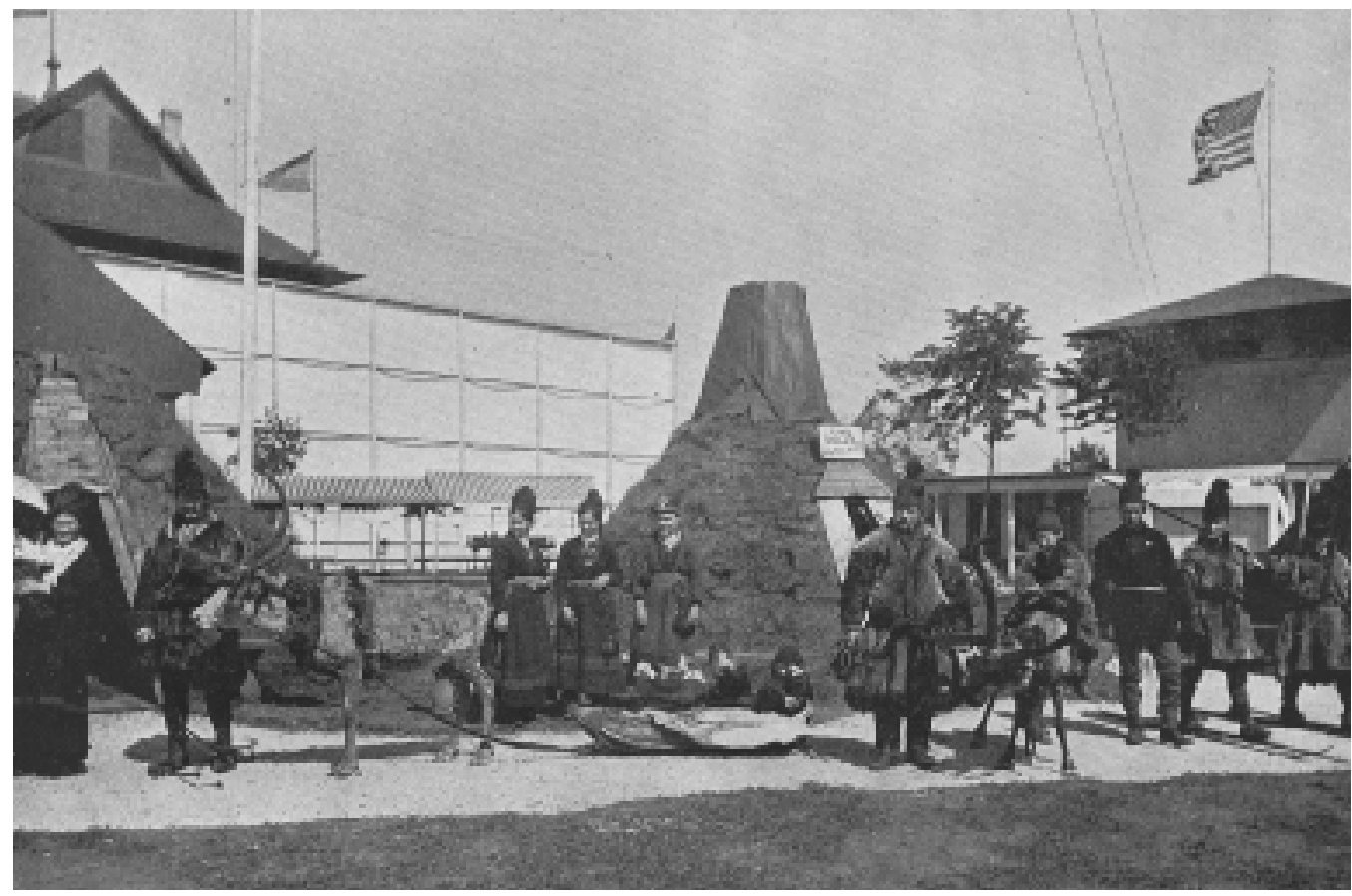

Fig. 2. "Some Arctic Visitors". Fra Lapland Village, verdensutstillinga i Chicago 1893. Foto: The American Eng. Co. Chicago. Kilde: Chicago History Museum.

Wien i 1872, verdensutstillingene i Paris i 1878 og 1889, på industriutstillinga i Glasgow i 1911, mens en "Lapland Village" for første og siste gang var en del av det offisielle programmet på verdensutstillinga i Chicago i 1893. Særlig ble verdensutstillinga i Paris i 1889 avgjørende for at denne formen for framstillinger av fremmede folkeslag også fikk gjennomslag på de store offisielle utstillingene i Europa, Amerika, Japan og andre steder. I Paris hadde mer enn 400 mennesker fra ikkevestlige kulturer blitt framstilt i rekonstruerte omgivelser, eller "native villages" som de ble kalt i denne sammenheng.

Men selv om utstillinger av eksotiske mennesker ble utbredt på de store internasjonale utstillingene i siste del av 1800-tallet, var det først og fremst dyrehagene som skulle tilby dem en permanent scene i Europa. Og virksomheten til dyrehandler og dyrehageeier Carl Hagenbeck i Hamburg var her helt avgjørende. I mer enn femti år skulle hans firma gjøre suksess både nasjonalt og internasjonalt med sine omreisende utstillinger av eksotiske dyr og mennesker med utgangspunkt i egen dyrehage. Dyrehager hadde på dette tidspunktet fătt en enorm popularitet, ikke minst i Tyskland, og dette satte Hagenbeck på tanken om å innføre en ny attraksjon i tillegg til løver og elefanter. I 1875 engasjerte han en gruppe samer fra Karesuando og Tromsø til å illustrere "naturlivet" og reindriftsamenes levemåte 
110 ved hjelp av medbrakte redskaper, reinsdyr og gjeterhunder. Utstillinga ble en stor suksess, og allerede tre år etter var en ny gruppe samer på plass i Hamburg, denne gangen reindriftssamer fra Karasjok og Kautokeino. Så og si alle samer som deltok på de levende utstillingene ble rekruttert fra reindriftssamiske miljøer. Det store flertallet av samer som livnærte seg på andre måter enn gjennom reindrift, ble ikke ansett som tilstrekkelig autentiske for denne utstillingsformen. Etter de første utstillingene går det slag i slag, og i de kommende år ble Hagenbecks dyrehage befolket av "ville" folkeslag fra hele verden. Sommersesongen ble gjerne fylt opp med folk fra den sørlige halvkule, mens samer, inuitter og andre nordlige folk ofte trakk publikum i vinterhalvåret.

Under den voldsomme vekstperioden på 1870- og 80-tallet kom de levende utstillingene til å tiltrekke seg andre besøkende enn et nysgjerrig publikum. Med framveksten av antropologi som vitenskapelig disiplin fant forskere utstillingene tjenlige som komfortable feltlaboratorium for ulike undersøkelser, ikke minst fysisk antropologiske. Dette var for øvrig et forhold som tjente så vel utstillernes som de deltakende folkenes interesser ved at begrepet autentisitet nå ble viktig i diskusjonen rundt de levende utstillingene. Antropologenes undersøkelser ble en garantist for deltakernes kulturelle og rasemessige ekthet, og bidro dermed samtidig til å innlemme utstillingene i det moderne prosjekt.

De levende utstillingene fortsatte å øke i omfang fram til toppen var nådd rundt 1900-10. Den aller største utstillinga av fremmede folkeslag noensinne ser ut til å ha funnet sted på verdensutstillinga i Saint Louis i 1904. Her bestod den filippinske avdelinga alene av nærmere 1200 filippinere fra ulike etniske grupper som ble installert i gjenskapte lands- byer. Levende utstillinger av samer nådde imidlertid sitt absolutte høydepunkt med Ausstellung Nordland som fant sted i Berlin seks år seinere og hvor nærmere seksti samer fra Kiruna og Gällivare i Nord-Sverige deltok. Etter denne tid mistet de levende utstillingene sin fremtredende plass på de store internasjonale utstillingene. Praksisen med å framstille fremmede folkeslag fortsatte imidlertid ganske uforandret i dyrehager, på sirkus og i fornøyelsesparker, men nå nærmest utelukkende som en del av en voksende underholdningsindustri som utfoldet seg i opposisjon til høykultur, vitenskap og akademiske diskurser. På 1930-tallet synes også utstillingene av levende mennesker i disse kontekstene til å opphøre. Med noe geografisk variasjon avtar nå utstillingene markert, selv om det forekommer sporadiske utstillinger også etter denne tid.

\section{AKADEMISK DESINTERESSE}

De levende utstillingene var enormt populære i sin samtid. Lenge var de det ubestridt viktigste mediet for vanlig folks møte med fremmede kulturer. Særlig var verdensutstillingene enorme hendelser, selv etter dagens standard. For eksempel hevdes verdensutstillingen i Paris i 1889 å ha blitt besøkt av mer enn 33 millioner mennesker. Også de andre arenaene kunne framvise betydelige publikumstall, og selv om de ikke kunne konkurrere på størrelse, tok de det igjen på hyppighet. Særlig ble det avholdt mange og hyppige utstillinger av samer og reindriftsamisk kultur i Tyskland.

De levende utstillingenes popularitet i samtida står imidlertid i en påfallende kontrast til oppmerksomheten de har fătt i seinere forskning. For i motsetning til den etter hvert omfattende litteraturen om museenes og fotografienes betydning for forestillinger om kultur 

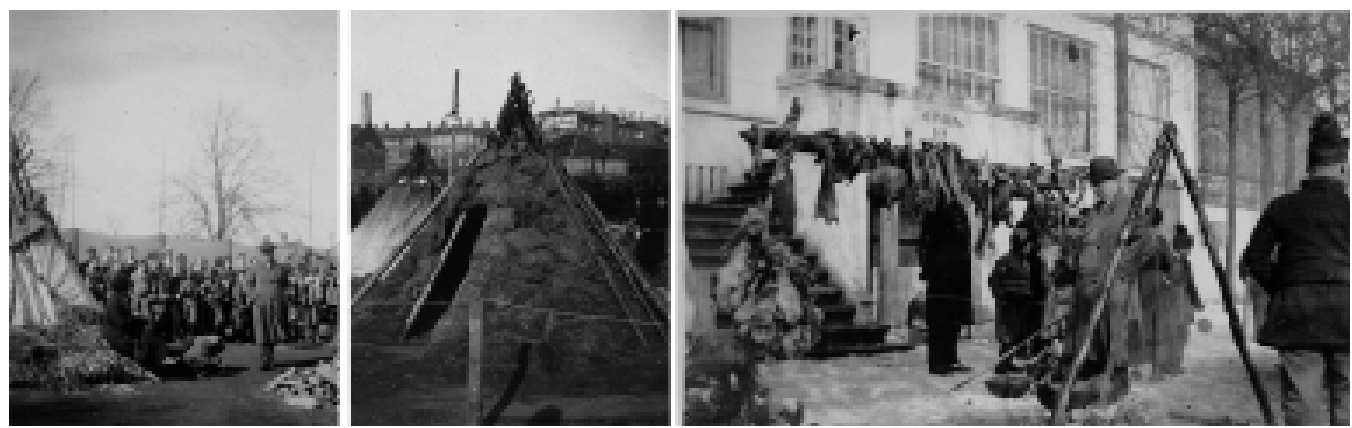

Fig. 3. Fra en av de siste levende utstillingene, familiene Danielsens opphold i Danmark i 1933. Mannen i frakk er trolig impresario Povl Neve. Kilde: Privat.

og kulturell fremmedhet, har praksisen med å utstille levende mennesker i liten grad blitt undersøkt av forskere, journalister og andre. Riktignok har temaet blitt behandlet innafor rammen av de store statlige utstillingene i seinere år (Schneider 1977, Benedict 1983, Rydell 1984, Greenhalgh 1991, Sánchez Gómes 2003)[b2], men utstillinger av mennesker i dyrehager, fornøyelsesparker og mer kommersielle sammenhenger har bare sporadisk blitt undersøkt.

Denne akademiske desinteressen ble påpekt av historikeren Gunnar Broberg allerede for tretti år siden, uten at nordiske forskere følte seg kallet til å ta fatt på oppgaven han da tegnet konturene av (Broberg 1981-82: 48). Og i den grad de levende utstillingene har blitt forsket på, eller omtalt, har oppfatningen av dem vært nærmest unisont negativ og moralsk fordømmende. Utstillingene har først og fremst blitt forstått som mer eller mindre utspekulerte iscenesettelser av rase og primitivitet innafor en vestlig hegemonisk diskurs basert på utbytting og undertrykking. Særlig har utstillinger i dyrehager blitt oppfattet som diagnostisk for $\mathrm{i}$ iscenesettelsen av kulturell for- skjellighet som underlegenhet og primitivitet. Ikke bare har man antatt at deltakerne ble grovt utnyttet og fornedret. Eller som Broberg slår fast samme sted som en oppsummering av virksomheten, i tillegg til at samene alltid lengtet hjem: "Givet är ändå att dessa resor snarare var transporter i bur än något annat" (Ibid. 1981-82: 36). Faktisk kan det virke som om dyrehagen som utstillingskontekst nærmest har blitt gjort selvforklarende på utstillingenes nedverdigende karakter, og dermed har gitt opphav til deres fordømmelse på et utelukkende moralsk grunnlag. Gjennom å la seg "lokke" eller "presse" til å framstilles kommersielt har man dessuten tatt det for gitt at de deltakende folkene kun har bidratt til å opprettholde myter og stereotypiske forestillinger om seg selv. Tilsvarende har utstillere og mellommenn ofte blitt forstått som rene utbyttere av kulturene de angivelig bidro til å forkleine. Denne ensidig negative forståelsen av de levende utstillingene har heller ikke gjort dem til et fenomen av større akademisk betydning, en betydning som synes å ha blitt ytterligere redusert gjennom deres forbindelse til kommersialisme og massekultur. 


\section{ProblemstiLLINGER OG TILNÆRMING}

Med utgangspunkt i denne dominerende forståelsen av de levende utstillingene har undersøkelsen av deres betydning som massemedium og "disiplinerende praksis" (Foucault 1980) vært en sentral problemstilling $\mathrm{i}$ avhandlinga. På hvilken måte kan de levende utstillingene ha bidratt til å forme - og spre bestemte oppfatninger om urfolk og minoriteter? En annen sentral problemstilling har vært de levende utstillingene som historisk fenomen og "sjanger". Hvor holdbar er den dominerende forståelsen av utstillingene som et produkt av 1800-tallets forestillinger om primitivitet og rase? Et ofte oversett faktum i den sammenheng er at utstillingene tilkommer forut for de rasemessige og evolusjonistiske rammene som seinere ble rådende. Forholder det seg ikke heller slik at de levende utstillingene var en del av en større, allerede eksisterende offentlig praksis for folkelig forlystelse og opplysning, og at denne praksisen i form og innhold skulle vise seg å passe godt inn i, og følgelig akselererte med og bidro til, de politiske og ideologiske diskursene som vant hegemoni på slutten av 1800-tallet?

I den sammenheng må det påpekes at de levende utstillingene på ingen måte var løsrevet fra andre mer konvensjonelle, museale framstillinger av kultur. Kronologien deres er i hovedsak samtidig med etableringa av de etnografiske museene og folkemuseene. En annen sentral problemstilling $\mathrm{i}$ avhandlinga har følgelig vært å undersøke i hvilken grad de levende utstillingene kom til å påvirke, eller selv ble påvirket av, andre samtidige utstillingsteknikker og representasjoner? Verdensutstillingenes betydning for museologiske framstillinger av (folke)kultur har lenge vært framhevet, og i Skandinavia da spesielt for de opple- velsesbaserte utstillingene til Artur Hazelius og Bernhard Olsen slik vi kjenner dem fra etableringa av Nordiska museet og Skansen i Stockholm samt Frilandsmuseet i København på slutten av 1800-tallet. En mindre vektlagt, og potensielt mer kontroversiell inspirasjonskilde, kan ha vært de levende utstillingene, og særlig de Carl Hagenbeck regisserte fra sin dyrehage.

Sist, men ikke minst, har de impliserte partene selv, og da særlig de samiske deltakerne, vært et sentralt anliggende $\mathrm{i}$ avhandlinga. Hvem var deltakerne, utstillerne og agentene, og hva har deres roller, opplevelser og motiver vært? Var relasjonene mellom dem så asymmetrisk som man har antatt? Deltakernes egne opplevelser av de levende utstillingene og motivene for å ha deltatt på dem har ikke bare blitt underkjent, avskrevet som uheldig eller utelatt i mange analyser av denne virksomheten. De har også nærmest utelukkende blitt framstilt som passive offer.

Som metodologisk ledetråd for tilnærminga til disse problemstillingene tok jeg utgangspunkt i Bruno Latours devise om å "følge aktørene selv" (Latour 2005: 12). "Recording not filtering out, describing not disciplining" - lyder oppfordringa fra Latour (Ibid. 2005: 55). Gjennom å bringe analysen ned på personplan og gi en detaljert empirisk redegjørelse for alle de involverte aktørene - også de ikke-menneskelige som gjenstander, reinsdyr, presse, kontrakter og utstillingsarenaer - har jeg ønsket å avdekke mangfold og aspekter ved de levende utstillingene som tidligere forskingsarbeider etter min mening ikke har vektlagt eller oversett. Særlig har jeg lagt vekt på å synliggjøre de samiske deltakernes identitet, forskjellighet og handlekraft. I den sammenheng har Latour's distinksjon mellom "intermediary" (som lydig transporterer me- 
ning uten å selv tilføre endring) og "mediator" (aktører som aktivt omformer) (Ibid. 2005: 39-40), vært sentral for å fokusere tydeligere på de oversettelses- og endringsprosesser de deltakende menneskene bidro til. Også i de påfølgende analysekapitlene gjøres det rede for hvordan stereotype og forutinntatte forestillinger har kommet til kort i forståelsen av de levende utstillingene, og at de deltakende folkene selv viser stor handlingskraft både på og utenfor "scenen". Dette gjelder også analysen av de levende utstillingenes forbindelse til vitenskap og (fysisk) antropologi.

\section{FORHOLDET TIL (FYSISK) ANTROPOLOGI}

Som nevnt innledningsvis kom de levende utstillingene i en periode, nærmere bestemt fra 1875 til ca. 1885/1890, til å fungere som feltlaboratorium for ulike vitenskapelige undersøkelser, og da særlig fysisk antropologiske. I denne antropologiens første fase var det å reise ut å gjøre feltarbeid uvanlig, og faget var i betydelig grad forbundet med studiet av folks fysiske framtoning. De levende utstillingene som brakte fremmede folkeslag til vestens storbyer og akademiske sentra, ble derfor naturlig nok en svært viktig kilde til data. I løpet av disse to tiårene ble det for eksempel foretatt et titalls etnografiske og fysisk antropologiske undersøkelser av minst fem omreisende samiske grupper. Undersøkelsene ble foretatt i regi av antropologiske selskap både i Tyskland, Storbritannia og Frankrike hvor utstillinger av samer ble utbredt, men Berlin antropologiske selskap og patologen Rudolf Virchow gjorde seg spesielt bemerket. I tillegg til å være Tysklands mest betydningsfulle antropolog ble Virchow de levende utstillingenes fremste vitenskapelige talsmann. I denne avgrensede perioden var utstillingene

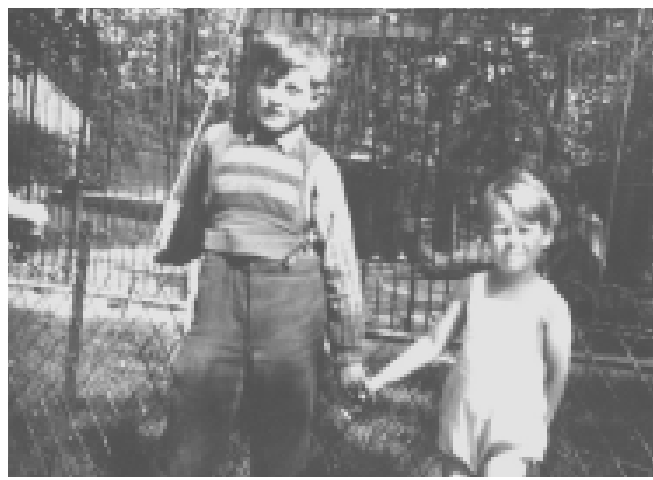

Fig. 4. Utstillingsdeltaker Trygue Danielsen (t.v.) fra Røros "off stage". Pa baksiden av bildet har han selv skrevet: "Minde fra Paris zoologiske have 29. angust 1933. Trygue med den norke sendemannens sønn". Kilde: Privat.

utvilsomt viktig i forhold til å naturalisere forestillinger om rase, utvikling og primitivitet, ikke minst gjennom akkumuleringa av antropologisk kunnskap som bruken av utstillingene som feltlaboratorium bidro til. Likevel argumenterer jeg for at betydningen av vitenskapelige diskurser har vært overdrevet $\mathrm{i}$ forståelsen av de levende utstillingene. Utstillingene hadde sin egen dynamikk som var relatert til andre, og til dels konkurrerende, syn på natur og kultur enn de som ble forfektet av vitenskapen. Produksjonen av antropologisk kunnskap skjedde dessuten ikke motstandsløst. Det foreligger flere vitnesbyrd både fra samiske deltakere og andre som kompliserer og nyanserer dominerende forståelser av de fysisk antropologiske undersøkelsene og resultatene de frambrakte.

\section{UTSTILLINGENS EGEN ETNOGRAFI}

Et annet sentralt poeng i min avhandling er at et ensidig fokus på imperialisme og undertrykking har gjort at man faktisk vet svært lite 
114 om de menneskene som deltok på de levende utstillingene. Utstillingenes egen etnografi har derfor vært det viktigste anliggende. I tillegg til å identifisere så mange deltakere som mulig har jeg gått inn i de enkelte utstillingskontekstene for i så stor grad som mulig å kartlegge hva som egentlig skjedde i møtet mellom utstiller, deltaker og publikum. For eksempel viste det seg at utstillinger av mennesker i dyrehager ikke skilte seg nevneverdig fra levende utstillinger andre steder, som de antatt mer høyverdige verdensutstillingene, og at forståelsen av dyrehagene som en særlig konnoterende scene for samtidas rasistiske og sosialdarwinistiske forståelser har vært betydelig overdrevet. Utstillingene her har i like stor grad vektlagt likhet og hjemlighet, der særlig barn og familieliv har stått sentralt, uten at dette har blitt tillagt vekt i tidligere analyser.
Et unntak er Eric Ames' bok om Carl Hagenbecks virksomhet (2008), som også har vært en viktig kilde til inspirasjon $\mathrm{i}$ arbeidet med avhandlinga.

Et tredje poeng i avhandlinga er mangfoldet av motivasjoner for å involvere seg i utstillingene, både fra deltakernes og utstillernes side. Alt har ikke handlet om økonomisk utbytte selv om dette trolig har vært den viktigste enkeltårsaken i begge disse henseender. Påfallende mange har heller ikke opplevd sin utstillingsdeltakelse som negativ og utbyttende. Tvert om kan det synes som om utstillingene har generert både muligheter og ressurser i ei tid der statlige programmer på ulike måter forsøkte å utradere - eller isolere - andre levemåter enn de vestlige. Til tross for at de ble utviklet for å tilfredsstille forventningene til et ikke-vestlig publikum, representerte utstilling-

Fig. 5. Omreisende museum? Utstillingsgruppe fra Frostviken ca. 1890. Kilde: Tromsø Museum - Universitetsmuseet.

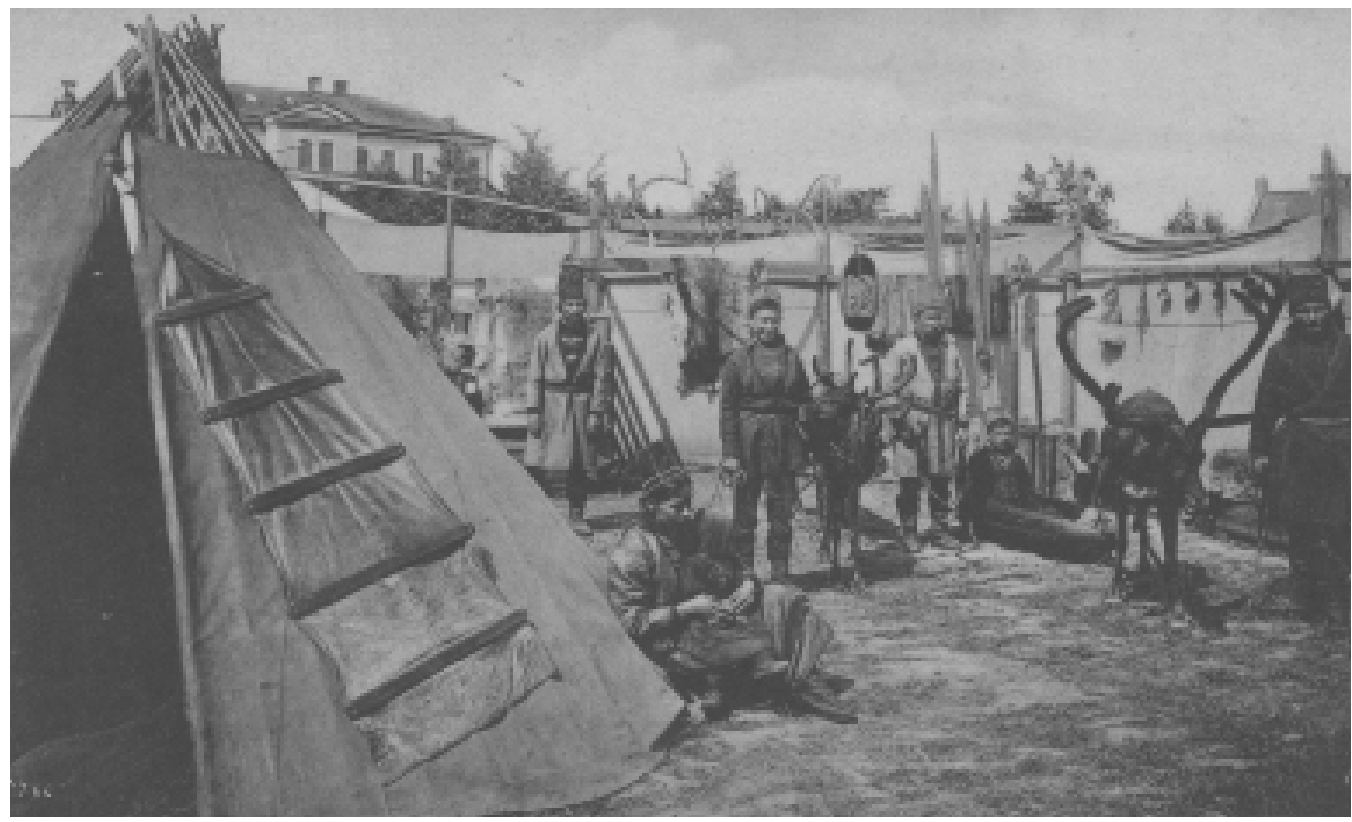


ene også en anledning for deltakerne til å formidle kunnskap om sin egen kultur, og til å uttrykke stolthet over sin levemåte og tradisjoner.

Et fjerde poeng $\mathrm{i}$ avhandlinga er betydninga av de levende utstillingene som "kontaktsone" (Pratt 1992, Clifford 1997), ikke bare mellom et vestlig publikum og "de andre", men også urfolk og minoriteter seg i mellom. Dette gjelder særlig verdensutstillingene hvor de ulike utstillingsdeltakerne levde side om side i de seks månedene utstillinga som regel varte. I henhold til mange forskere var urfolks globale bevissthet et fenomen som først oppsto på 1960- og 70-tallet, gjerne som resultat av en postmoderne identitetspolitikk påført utenifra. For eksempel framholder historikeren Henry Minde at det ikke foreligger vitnesbyrd om at samene sammenlignet sin situasjon med andre urfolk før artikkelen "Samene er Sveriges indianere" utkom i tidsskriftet Samefolket i 1963 (Minde 2003). Selv om vitnesbyrd om en slik sammenligning kanskje ikke lar seg etterspore umiddelbart i tradisjonelle, skriftlige kilder, er det ingen tvil om at de levende utstillingene, og da i særlig grad verdensutstillingene, utgjorde en ny og globalisert kontekst som må ha brakt mange av de deltakende folkene til bevissthet om at deres historie ikke var isolerte "tilfeller", men at de tvert om delte skjebne med mange andre. Et eksempel på dette representerer trolig den kjente samerettsforkjemperen Daniel Mortensson som deltok på verdensutstillinga i Chicago i 1893, og som seinere ble sentral i det samiske organisasjonsarbeidet i første del av 1900-tallet.

\section{DE LEVENDE UTSTILLINGERS VIRKNINGSHISTORIE}

Til sist i avhandlinga løftes det fram to viktige virkningshistoriske effekter av de levende ut- stillingene. Den første er betydningen som sjangerskaper for framstillinger av kultur på museum. Vesentlig i den sammenheng er den realistiske eller autentiske rekonstruksjonen som ble ansett som en selvfølgelig utstillingsform når museet vant hegemoni som legitim formidler av kulturell forskjellighet fra slutten av 1800-tallet. Museene gjorde på mange vis den realistiske rekonstruksjonen stuerein, ikke bare fordi den baserte seg på materielle rekvisita, voksdukker, objekter og tekster istedenfor levende mennesker. Museene ga også representasjonen en "korrekt" institusjonell sammenheng som garanterte for dens seriøsitet. Likevel kan det påpekes at denne "rensingen" og "avpolitiseringen" av uttrykket reiste sine egne etiske spørsmål. I museene ble kontrollen over representasjonen nærmest totalt overgitt utstillerne. I de levende utstillingene hadde samer og andre urfolk tross alt hatt en medvirkning. Når som helst kunne utstillingsdeltakerne selv - eller dyrene deres - gripe inn og endre eller "forstyrre" representasjonen. I museet forsvant denne muligheten helt ut. Først på 1970- og 80-tallet, ble den igjen gjort til gjenstand for forhandlinger.

Den andre virkningshistoriske effekten som drøftes er de levende utstillingene som skaper av bevissthet og kulturell kapital. Selv om deltakelsen på de levende utstillingene utvilsomt også bidro til en politisk bevisstgjøring for noen, som for eksempel Daniel Mortensson, er det i første rekke iscenesettelser av samisk liv $\mathrm{i}$ et næringsrettet formål som har vært mitt anliggende. Og her kan man nærmest snakke om en direkte videreføring med den forskjell at samene selv har tatt over regien. Mange av de kulturelle forestillingene og formidlingsformene som ble skapt gjennom de levende utstillingene kan sies å leve videre $\mathrm{i}$ dagens samiske kulturisme og kulturarvsindustri. Mange av 
116 disse har også blitt kritisert som uekte, som salg av kultur og tap av sjel, en kritikk som virker påfallende lik den som fra ulike hold har blitt rettet mot de levende utstillingene, ikke minst fra akademikere.

De levende utstillingene utgjorde et antatt episodisk og nærmest glemt fenomen både i forskning og blant folk flest. Og i den grad man kjente til dem var oppfatningen ensidig negativ og fordømmende. Selve fenomenet overflødigjorde så å si en videre vurdering og fortolkning. Men som jeg håper å ha vist $\mathrm{i}$ avhandlinga: også når problematiske praksiser undersøkes og aktører følges, så avdekkes andre og konkurrerende perspektiv.

\section{LITTERATUR}

Ames, Eric: Carl Hagenbeck's Empire of Entertainments. University of Washington Press: Seattle 2008.

Baglo, Cathrine: På ville veger? Levende utstillinger av samer i Europa og Amerika. Institutt for arkeologi og sosialantropologi. Universitetet i Tromsø: 2011.

Benedict, Burton: The Anthropology of World's Fairs. The Lowie Museum of Anthropology/Scholar Press: London og Berkeley 1983.

Broberg, Gunnar: Lappkaravaner på villovägar. Antropologin och synen på samerna fram mot sekelskiftet 1900. Lychnos. 1981-82: 27-85.

Clifford, James: Routes. Travel and Translation in the late Twentieth Century. Harvard University Press: Cambridge, London og Massachusetts 1997.

Foucault, Michel: Power/Knowledge. Selected Interviews and Other Writings, 1972-1977. C. Gordon (red.). Pantheon: New York 1980.

Greenhalgh, Paul: Ephemeral Vistas. The Expositions Universelles, Great Exhibitions and World's Fairs, 1851-1939. Manchester University Press: Manchester 1991.
Latour, Bruno: Reassembling the Social. Oxford University Press: Oxford 2005.

Minde, Henry: The Challenge of Indigenism: The Struggle for Sami Land Rights and Self-Government in Norway 1960-2000. Indigenous Peoples: Resource Management and Global Rights. S. Jentoft, H. Minde og R. Nilsen (red.). Eburon Delft: Delft 2003.

Pratt, Mary Louise: Imperial Eyes. Travel Writing and Transculturation. Routledge: London og New York 1992.

Rydell, Robert W.: All the World's a Fair. Visions of Empire at American International Expositions, 1876-1916. The University of Chicago Press: Chicago og London 1984.

Sánchez Gómez, Luis Ángel: Un imperio en la vitrina. El colonialismo español en el pácifico y la exposición de filipinas de 1887. Consejo superior de investigaciónes científicas: Madrid 2003.

Schneider, William: Race and Empire: The Rise of Popular Ethnography in the Late Nineteenth Century. Journal of Popular Culture. Nr. 11, 1977: 98-109.

Wonders, Karen: Habitat Dioramas. Illusions of Wilderness in Museums of Natural History. Acta Universitatis Upsaliensis: Uppsala 1993.

* Cathrine Baglo disputerte nylig for Ph.D-graden ved Universitetet $i$ Tromsø, Institutt for arkeologi og sosialantropologi. Hun er for tiden ansatt ved Tromsø Museum - Universitetsmuseet hvor hun også hadde sin arbeidsplass som stipendiat.

Address: Seksjon for kulturvitenskap Tromsø Museum - Universitetsmuseet NO-9037 Tromsø, Norge

E-mail: cathrine.baglo@uit.no 